細胞膜分解による澱粉分離（その 1 )*

菌株について

本江元吉, 栗栖敏 郎 (九州大学檂学部農芸化学教室)

昭和 33 年 8 月 2 日受理

ある種の細菌が生甘藷の切片に働いて細胞膜を分解し澱粉粒を遊離することについては，かなり以前からこの 種の操作による澱粉製造の可能性が考光られていたが，最近和田によって研究の端緒が開かれた(1).しかしこの 方面の研究は明確ではなく，例えばその菌が何であるかも菌学的によくしらべられていない，というのも，この 菌株の純粹分離が困難だったからである。たまたま鹿大の蟹江教授からこの種の菌株の分譲を受けた．この分譲 菌株も生甘藷切片に殺菌水を加えた培地中にだけ生育するといわれ，事害加糖肉汁などの普通に使用する培地に 接種し，生育してきた培養について生甘藷切片の崩買を検した結果はことごとく負であった。こんなところに従 来純粋分離が困難であった原因が考えられる．それでこの菌株の純粋分離を企て，その結果純粋にできた菌株に ついて菌学的性質を検し，分類上の位置を確かめた，その次第を報告する．

実

験

\title{
I. 純粋分離
}

粗培養を普通の培地に接種すると, 婎気的にしても污染菌がもっぱら繁殖してこの生甘藷切片崩壊能（以下甘 藷崩墒能々略)をるっている菌の生育が抑えられる，それでいろいる検索した結果，馬鈴薯计を主体とする培地 を使用することにした。これは馬鉿薯をオロシガネでおろし濾紙で滤過した濾液に寒天 $2 \%$ を加え（2 kg，40 分 殺菌)，これに Difco の brewer anaerobic agar** (1 kg，40 分殺菌）を等量加克た培地である. anaerobic agar を加光たのは馬鈴薯计寒天だけでは生育が必ずしも充分ではないからである．この培地で平面培着を行い， 嫌気解儿培美して主じょコロニーをとって甘藷崩壊能を検すると，明らかにとの性能があり，分離の方法が決 った.

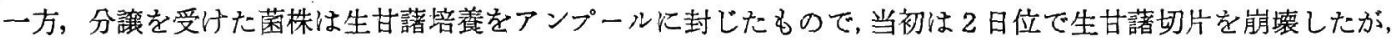
15 日前後の放置（室温及び $4^{\circ}$ ) によって極端に甘藷崩壊能が減少した，性能回復の条件を検したところ，生甘 藷切片に殺菌水を加えたもので移植培養をくりかえすこと汇よって性能を強化できた．はじめ甘藷崩壊に1週間 余りを要した衰弱培湌も移植約 10 回で 10 時間前後に短縮できた。この強化粗培養をもとにして上記の方法で平 面培養し、コロニーを馬鈴著汁・ダルンース・硫酸アンモニウム・炭酸石灰の培地(2)にとって培養し，甘藷崩壊

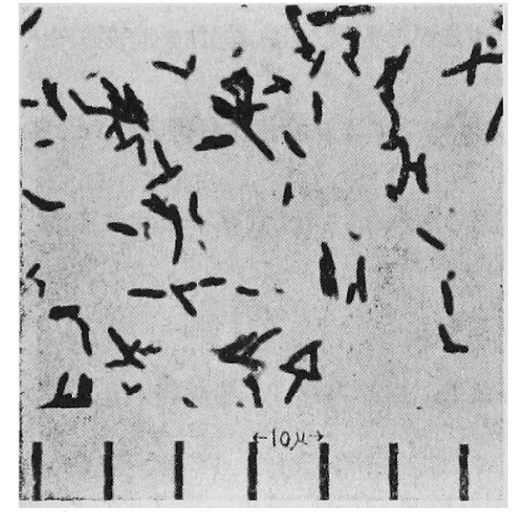

第 1 図栄養細胞（24 時間培養） 能を検した後平面培盖するといら操作を 5 回くりか觉して純粋に した．な拈，实験中にこの菌が耐熱性胞子をつくることがわかっ たので $80^{\circ}, 10$ 分の熱処理䍇汰もコロニー分離の間の培荃で行っ た.

このよラにして得られた純粋培養について，次の形態的及び生 理的諸性質を検した.

II. 菌学的性孟

A. 形態（馬鈴薯汁・グルュース・硫安・炭石の培地, $33^{\circ}$, 排気法に上る媒気培盖)

栄着細胞 (24 洔間培䬭)：端部は丸味ある桿状細胞. 単独变れに 2 個連結. $2.0 \sim 6.0 \times 0.4 \sim 0.8 \mu$ ，大部分 $4.5 \times 0.6 \mu$ (第 1 図).

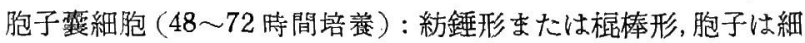

* Isolation of Starch Granules from Sweet Potato by Decomposing its Tissues with Bacteria.

Part I. On the Strain.

By Motoyoshi Hongo and Toshiro Kurusu (Department of Agricultural Chemistry, Faculty of Agriculture, Kyushu University)

題目结研究の先䩒をつけら机た和田女史に敬意を表して同題目とした。

**ペプトン，酵母エキス，グルコースなどの外に酸化還元電位を下げるように thioglycollate が入って招り， rH indicator の Resazurin る入っている. 


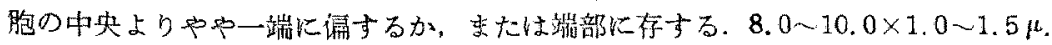

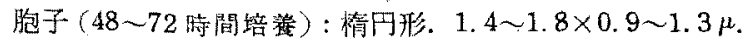

運動性: 若い栄荃細胞は活発に運動する。

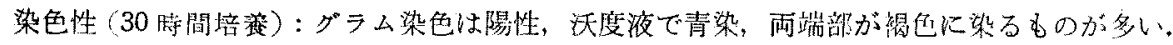

\section{B. 培 養}

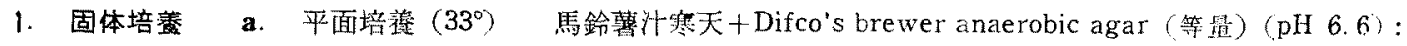
踭気下 2 日でコロニ一生成. $4 \sim 5$ 日で表面コロニ一は直径 $2.0 \sim 4.0 \mathrm{~mm}$, 正丹形（後不正円形）隆起し周辺な めらか, 半透明で灰白色, 湿潤, 光沢, 粘性, 培養には強いアせトン・ブタノール臭あり。深部ニロニーは 1.0 $\sim 2.0 \mathrm{~mm}$, レンズ形，灰白色やや不㴡明。

グルコース (1\% 添加) 肉汁寒天：呼気下 4 5 日で 0.5 1.0 mm のコロニ-生成, 深部に生じレンズ形で

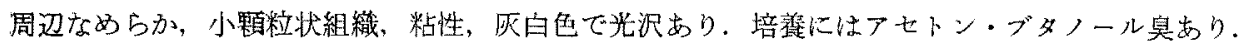

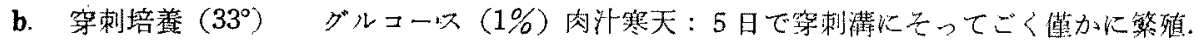

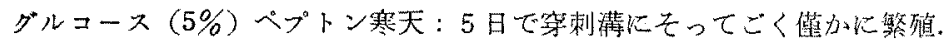

㢣汁 $\left(5^{\circ} \mathrm{Bllg}\right)$ 寒天: 繁殖しない。

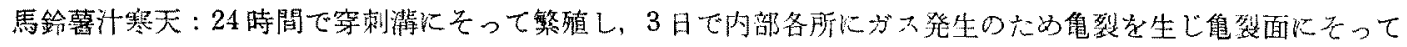
コロニーを生ずる。裂げた寒天はガスのため押し上げられる。

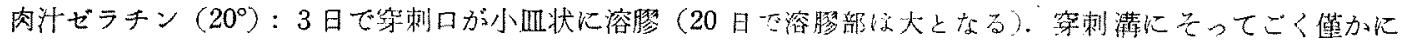
繁殖.

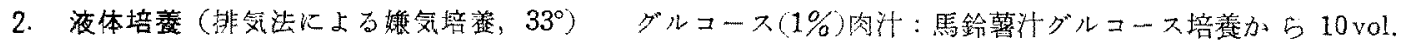

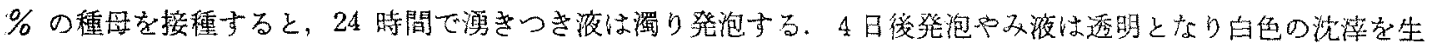

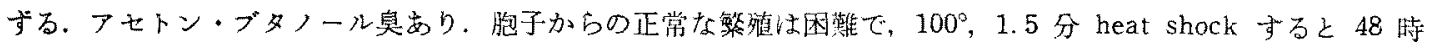
閒後に至って液は僅かに濁るが発泡はとの後も認められない。

肉汁: 繁殖しない.

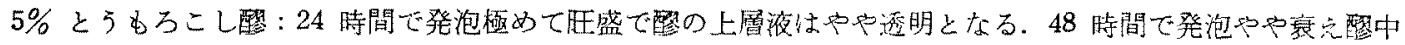
の固形物粘質物は液全体に拡がる.72時間で発泡とまり漼は透明となり固形物粘質物は沈降する。

耑鈴著汁・グルコース・硫安・炭石培地：24 時間で盛ん汇発泡し上暗は黄白色の夜となる.48時間で発泡を 続け白い粘質物を中位置に生ずる.72 時間で発泡衰文液は淡黄色になり馬鈴暮の残椬は沈降する.7日後強いア セトン・ブダール臭がある。

牛乳：24恃間で盛んK発泡し上面に多くの気泡を生ずる.カゼインは全体にわたって㠜固してくる.48時間

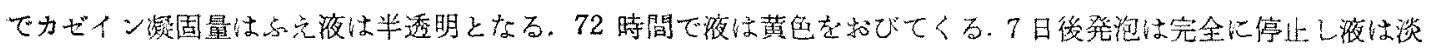
黄色透明，凝固物心变化なし，14 日後变化なく凝固物のペプトン化はみられない，

リトマス牛乳：24 時間で盛えK発泡し上面に多くの気泡を生じ，カゼイン况凝固し液は赫褐色となる.48 時

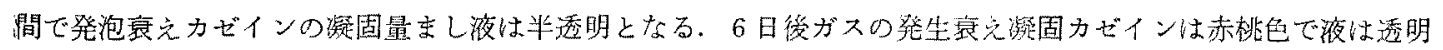
な桃褐色を呈する。

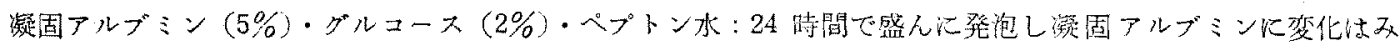

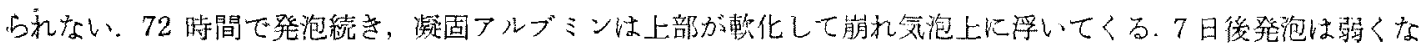
り㠜固アルブミン上半部は灰褐色々なり小さく崩れる.

酵母本：僅的繁殖.

C. 生 理

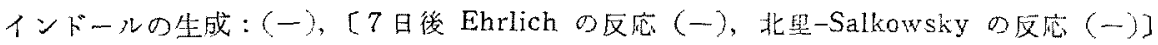

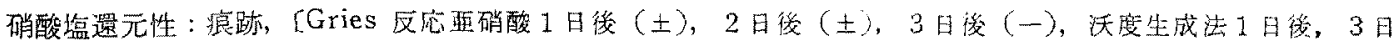
後, 10 日後之もに

亜硝酸塩還元性: (十) [ Gries 反応悪硝酸 4 日後 $(-)$ ]

アンモニア生成: $(+)$.

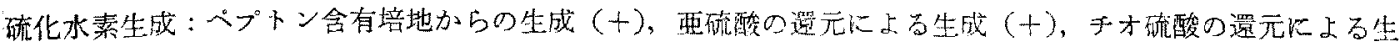




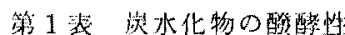

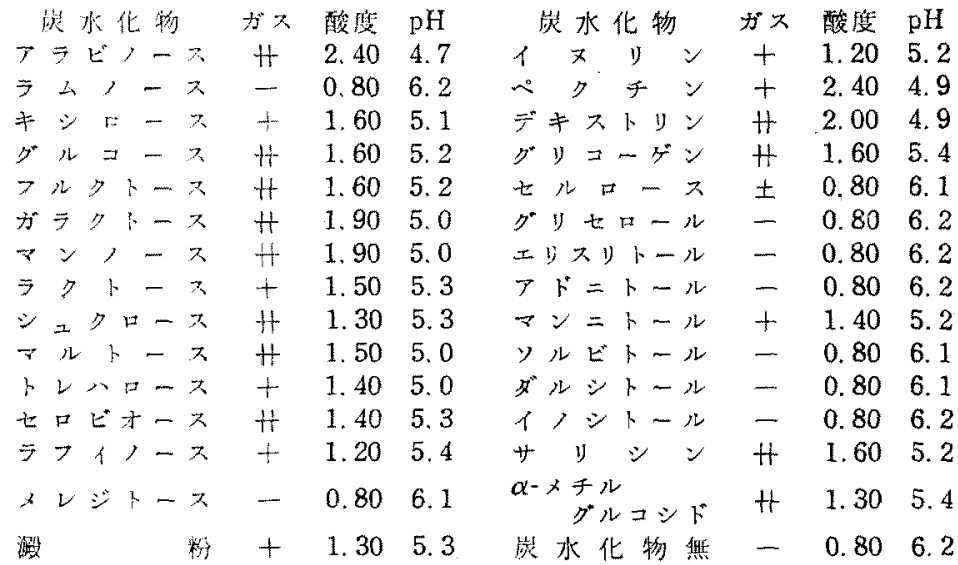

成 $(t)$.

カタラーゼ存在 : (一).

色素：生成しない。

胞子の附熱性：72時間培差中 の胞子は馬鈴薯计・グルコース 培地で $100^{\circ} ， 5$ 分の加熱比耐え る.

$\mathrm{pH}$ : 最適 5.6〜7.3，繁殖可 能籍囲 $4.2 \sim 8.8$.

温度：最適 $33^{\circ}$.

好婎気性：嗝性嫌気性。

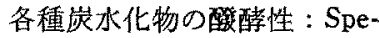
akman の塩液 (ペプトン0.5\% 源加, $\mathrm{pH}$ 6.6) K各種の炭水化

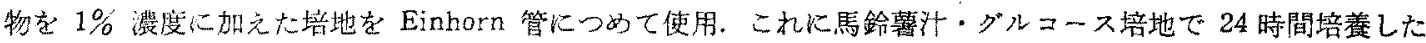

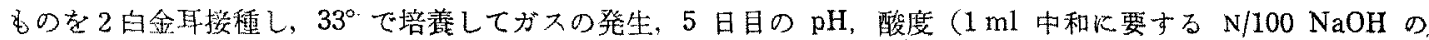

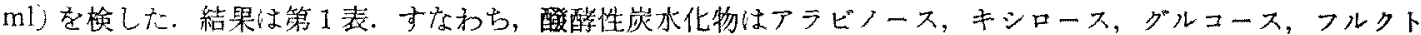
一ス, ガシクトース, マンノース, ラクトース, シニクロ一ス, マルト一ス, トレハロ一ス, 女ロピオース, ラ

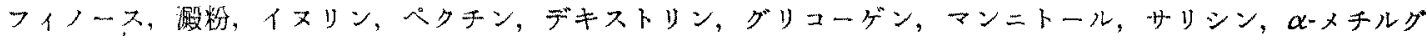
ルコシドで，非醴醅性炭水化物はシムノ一ス，メレジトース，グリセロール，エリスりトール，アドニトール，

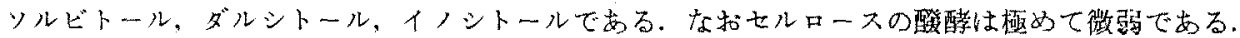

III. 類 緑

以上の諸性質から Bergey's Manual of Determinative Bacteriology 6 版 (1948)によって䋑を求めると, Clostridium acetobutylicum McCoy, Peterson, Fred, Hastings になる.些細な点では硝酸塩還元性と pectin

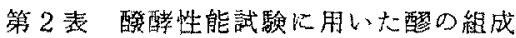

瀷

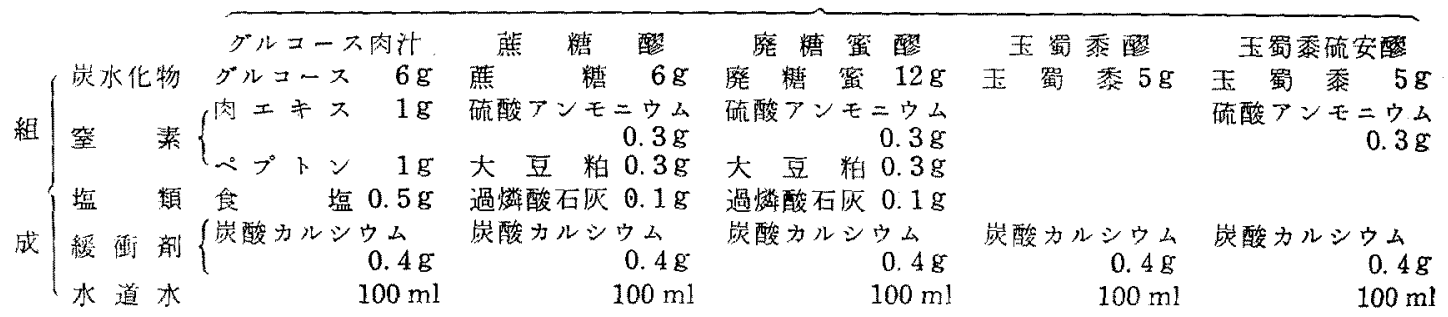

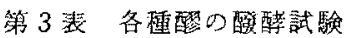

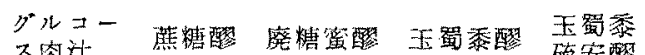

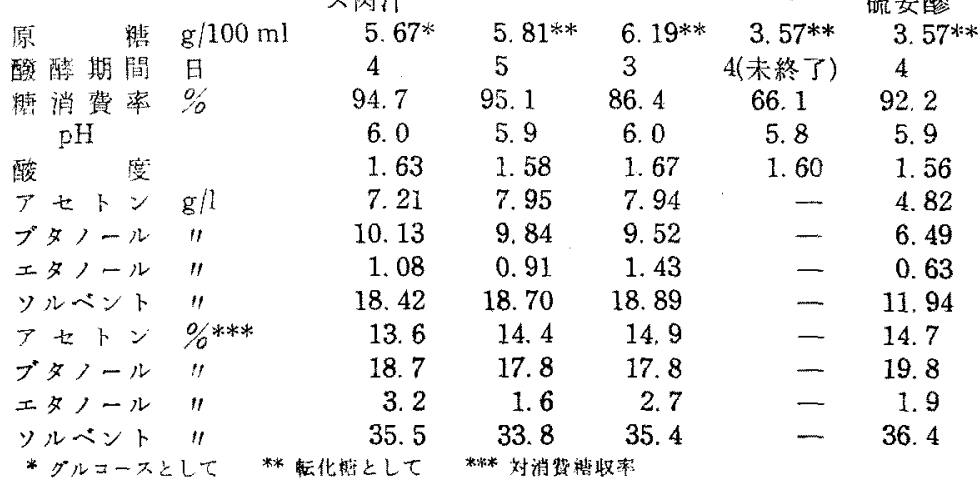

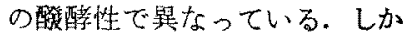
し，これらはこの菌種に属する 諸菌株で普通にみられる相遠で

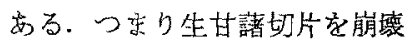
する氛はアせトン・ブタノール 菌であった訳である。

\section{IV. 醅醉性能}

つきにこの菌株のソルベント 生成能を检した。醪には第 2 表 に示す組成の\&のを用いた。馬 鈴警计・グルコース培地て heat shock 培㦈後, 间培地で2回, 


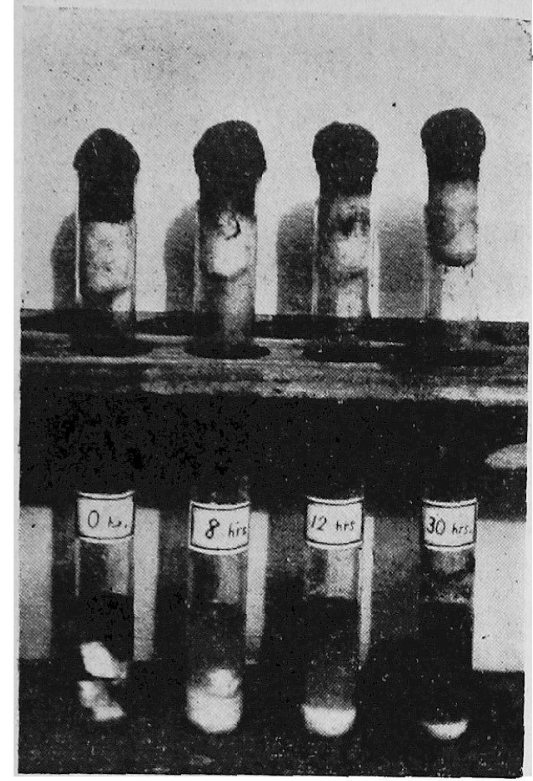

第 2 図生甘藷切片崩壇

主膠と同じ組成の醪で 1 回移植した種菌を $10 \mathrm{vol} \%$ 星接種して $33^{\circ}$ で䁔酵させた結果は第 3 裴.つまり Weizmann 型と同じく らいの土タノールをつくるが，アセトンが多く，末た硫安をよく 利用する点で違っている。この菌梏番号を S 1 とし, Clostridium acetobutylicum S 1 とする.

V. 他のブタノール菌の生甘諸切片崩壊能

生甘藷崩壊能をむつ菌株がブタノール菌であったから，他のブ タノール菌も同様の甘藷崩壊能をもちはしないかと考兊られるの で，教室保存の Weizmann 型ブタノール諸菌株や Saccharo 型 ブタノール諸菌株, イソプロパノール諸菌株についてこの性能を 検した. その5ち Weizmann 型の Clostridium acetobutylicum 314-48 株にごく㐆弱にこの性能が認められたに方ぎなかった。っ

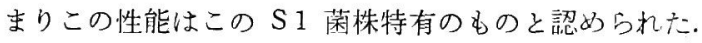

VI. 保 存

この S 1 株は胞子をつくる Cl. acetobutylicum ときまったの で，常法にしたがいこれを砂培踽にして保存してみた。今までに 数カ月を経たこの砂培養老馬鈴薯汁・グルコース培地に加えて heat shockし，生育してきた培養をとって甘藷崩壊能を検した 結果は第 2 図に示すよ5に，強性能で衰光ていなかった。したがってこの菌株はもはや常に植えかるを要する生 甘藷・殺菌水培養のアンプールとい5ような不安定で污染菌の入った粗培荃の状態で保存する必要はなく，純粋 で安定な砂培養として保存できる。なお，Vの試験に供した他の諸菌株は甘藷崩壊能を強化する移植操作をそれ 任ど経ていない点に多少の疑問を残していたものであるが，この胞子保存の砂培盖から heat shock 培盖した名 のが生甘墸で移植しないでもすぐに強い甘藷崩壊能を示す点から，この種の疑問はなくなる。

総

括

殺菌水中の生甘諸の切片を崩壞して測粉粒を遊離する細囷株は，従来性能低下を防ぐため一週間前传で移植す る必要があり，また生甘諸切片・殺菌水という培地にしか生えないとされていたため純粋分離ができなかった。 培地検索の末，馬鈴薯汁寒天に Difco's brewer anaerobic agar を等量加えた培地を使用することによって,こ の菌株を純粋に分離できた。ついで菌学的諸性質を検した結果，Clostridium acetobutylicumに属しWeizmann

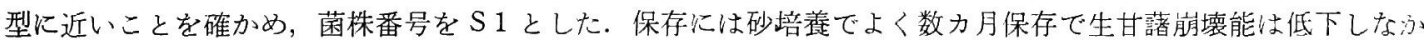
った。な括手持ちの他のブタノール菌数十株について検したが，生甘諸能偯能はほとんど認められなかった。

終りに菌株の分譲を頂いた鹿大昷江教授に深謝する。

（1）和田 水：日本農芸化学会大会(昭 32) 飞 さ机た。 講演発表の予定であったが，都合汇より中止

(2) 本江元占, 長田 煡 : 本挽, 32, 454(1958), 